\title{
Effect of irrigation on soil salinity profiles along the Lower Vaal River, South Africa
}

\author{
PAL le Roux*, CC du Preez, MG Strydom, LD van Rensburg and ATP Bennie \\ Department of Soil, Crop and Climate Sciences, University of the Free State, PO Box 339, Bloemfontein 9300, South Africa
}

\begin{abstract}
The impact of long-term irrigation on semi-arid soils along the Lower Vaal River in central South Africa was assessed. Irrigated sandy and clayey soils representative of relatively homogeneous agro-ecosystems were sampled at $200 \mathrm{~mm}$ intervals to a depth of $2 \mathrm{~m}$ wherever possible. To serve as a reference, adjacent virgin soils were sampled wherever possible. All the samples were analysed for common salinity indicators. Soils irrigated for more than 20 years with water varying in electrical conductivity (EC) from 52 to $74 \mathrm{mS} \cdot \mathrm{m}^{-1}$ and sodium adsorption ration (SAR) of $<5$ reacted differently. Salts were generally less and more evenly distributed in the virgin profiles than in their irrigated equivalents. In the irrigated clayey soil at Spitskop the salt content increased with depth. In the irrigated sandy soil at Vaalharts maximum salt accumulation occurred above the water table, whereas in the centre pivot irrigated sandy soil at Wildeklawer it occurred at 400 to $800 \mathrm{~mm}$ depth. In the latter case the salt accumulation is linked to water uptake by crops probably due to limited water application. In the irrigated sandy soil at Zandbult salt accumulation at $1100 \mathrm{~mm}$ depth was linked to a period of irrigation with low quality water. In spite of a general increase in salinity the soils were not physically severely degraded. Where water tables occurred in sands the salinity reached levels where it will affect sensitive crops. In the Spitskopdam clay soil it reached levels affecting tolerant crops. However, the accumulated salt load varied between sand and clay soils and improved irrigation scheduling practices that do not allow additional water for salt leaching; this may lead to increased salinity and degradation of the irrigated soils.
\end{abstract}

Keywords: primary salinity, secondary salinity, water logged

\section{Introduction}

The natural resource base, in particular soil and water, together with the entrepreneurial capacity forms the basis for economic activities related to irrigation (Backeberg, 2003). Surveys conducted by Nell and Van den Berg (2001) on land potentially available for irrigation in South Africa, revealed that a total of $1.6 \times 10^{6}$ ha, comprised of $1.1 \times 10^{6}$ ha for temporary irrigation and $0.5 \times 10^{6}$ ha for permanent irrigation (sugar-cane included). Backtracking land allocation to the eighties showed that an area of $1.23 \times 10^{6}$ ha was irrigated, with a possible expansion of 0.25 x $10^{6}$ ha (Scotney and Van der Merwe, 1995). Department of Water Affairs (DWAF, 1996), as cited by Backeberg (2003), projected that the potential for irrigation to expand was limited by water availability, as official estimates indicated an expansion of irrigated land by 178000 ha. However, all these studies had a similar deduction, namely that the natural resources, water and soil, allocated for irrigation were used to their fullest potential, and that maintenance of its quality needed all the attention it deserves. This conclusion was supported by salinity research, which indicates that between $1 \%$ and $12 \%$ of the total irrigation area, depending on the provinces, is severely water-logged or salt-affected, and $5 \%$ to $20 \%$ is moderately affected (Water Research Commission, 1996).

Several factors could influence the salinity levels of irrigated land. One of the factors is the irrigation method. A recent survey showed that sprinkler systems cover $53 \%$ of the total area under irrigation, while surface irrigation systems account for

\footnotetext{
* To whom all correspondence should be addressed.

前 +27 51 401-2386; fax: +27 51 401-2212;

e-mail: LeRoux.SCI@ufs.ac.za

Received 20 June 2006; accepted in revised form 14 May 2007.
}

$28.5 \%$ and micro- and drip-systems for $18.5 \%$ (Water Research Commission, 1999). The efficiency levels of irrigation systems vary between 55 and $65 \%$ for surface irrigation, 70 and $85 \%$ for sprinkler irrigation and 85 and $95 \%$ for micro/drip irrigation. Irrigators compensate for the inefficiency of irrigation systems by applying more water than the potential crop water demand. Hence, it can be expected that over-irrigation occurs where flood irrigation is practiced and a lack of leaching could occur where more sophisticated methods are used. Soil characteristics such as inherent salt content, internal and external drainage also play an important role in ensuring sustainable soil salinity levels. Fortunately, very strict soil suitability standards were used for the allocation of irrigation land. Today, $87 \%$ of the total area under irrigation is classified as suitable to very suitable for its purpose (Water Research Commission, 1996).

Scotney and Van der Merwe (1995) stated that water quality poses one of the greatest threats to the sustainable use of irrigated soils. A comprehensive investigation, which focused amongst other factors, on the change in water quality of the Lower Vaal River and its tributaries, confirmed their concern regarding water quality (Du Preez et al., 2000). This study showed that the quality of water in the Lower Vaal River has deteriorated over the past 20 years and that it is expected to deteriorate even further. This deterioration was expected since most of the wastewater of Gauteng, South Africa's most densely populated province, ends up in the Lower Vaal River, which serves as water source for a significant portion of the country's irrigation land. Periodic supply of irrigation water with poor quality has resulted in crop failures along the Lower Vaal River and the sustainability of irrigation farming in this region has become questionable. This paper reports on the impact of irrigation in this region on soil quality, more specifically the redistribution and accumulation of salts in sandy and clayey soils. 


\section{Methodology}

This study is part of a bigger project reported on by Du Preez et al. (2000). The study area stretches over $200 \mathrm{~km}$ from Vaalharts to Jackson (Fig. 1), with a drastic change in climate downstream (Table 1). At five representative sites, viz. Vaalharts, Spitskop,

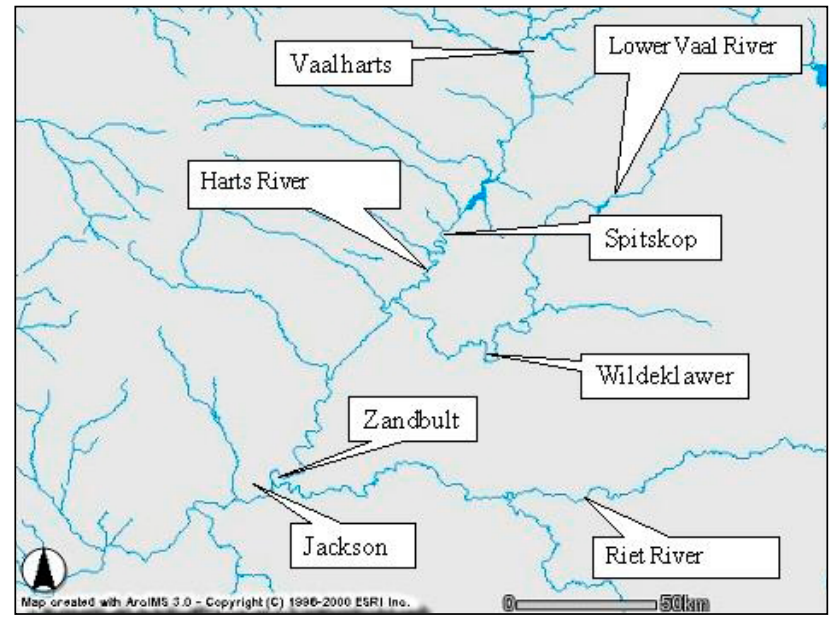

Figure 1

Map of the study area showing the main river systems and the five selected sites

\begin{tabular}{|l|c|c|c|}
\hline \multicolumn{4}{|c|}{ TABLE 1 } \\
\begin{tabular}{|} 
Climate at extreme ends of the study area \\
(Land Type Survey Staff, 1986)
\end{tabular} \\
\hline Location & $\begin{array}{c}\text { Rainfall } \\
\text { (mm) }\end{array}$ & $\begin{array}{c}\text { A pan } \\
\text { evaporation (mm) }\end{array}$ & $\begin{array}{c}\text { Aridity } \\
\text { index }\end{array}$ \\
\hline Vaalharts & 442 & 2523 & 0.18 \\
\hline Jackson & 315 & 3219 & 0.10 \\
\hline
\end{tabular}

Wildeklawer, Zandbult and Jackson, an irrigated soil and adjacent virgin soil were sampled. Representative soils irrigated for more than 20 years with Lower Vaal River water were selected. In addition, irrigated soils with artificial drainage were included in the surveys at Vaalharts and Jackson.

At each site, a soil pit was dug at a representative position in the landscape, the soil profile described, classified (Soil Classification Working Group, 1991), and samples taken in March 1998 for analyses. The predetermined sampling depth of 2000 $\mathrm{mm}$ was not achievable in some places due to a hard layer in dry clayey soils, or a water table in some irrigated soils. Soil profiles were sampled in $200 \mathrm{~mm}$ increments from the bottom of the pit upwards, to prevent contamination of samples.

The soil samples were dried at about $40^{\circ} \mathrm{C}$, crushed to pass through a $2 \mathrm{~mm}$ sieve, mixed thoroughly and stored in glass bottles until analysed using standard methods (The Non-Affiliated Soil Analysis Work Committee, 1990). The soils were analysed for soil properties that could change under irrigation. This paper focuses on the electrical conductivity (EC) of the saturated extracts $\left(\mathrm{EC}_{\mathrm{e}}\right)$ of the soils.

The salt load was estimated by converting $\mathrm{EC}_{\mathrm{e}}$ to total dissolved solids (TDS) $\left(\mathrm{EC}_{\mathrm{e}} * 6.5=\mathrm{TDS}\right)$ (Richards, 1969). As the clay content and the gravimetrical water content of the saturated paste $(\theta \mathrm{sp})$ of the layers varied very little within the profiles, an average $\theta$ sp value for all layers of a profile was used in the calculation, together with an average bulk density of $1650 \mathrm{~kg} \cdot \mathrm{m}^{3}$.

\section{Results and discussion}

A general description of the soils at each site is given in Table 2. The soils were either sandy or clayey, with the sandy soils containing $5 \%$ to $10 \%$ clay and clayey soils, $40 \%$ to $60 \%$ clay. The sandy soils belong to the Hutton, Bainsvlei and Bloemdal forms (Soil Classification Working Group, 1991) or fine sandy Quartzipsamments (Soil Survey Staff, 1999). The clayey soils

\begin{tabular}{|c|c|c|c|c|c|c|c|c|}
\hline \multicolumn{9}{|c|}{$\begin{array}{c}\text { TABLE } 2 \\
\text { General description of the sampling sites and the particle size distribution of the } s\end{array}$} \\
\hline \multicolumn{3}{|l|}{ Site description } & \multicolumn{6}{|c|}{ Average particle size distribution (\%) } \\
\hline Profile (soil form) & $\begin{array}{l}\text { Irrigation } \\
\text { method }\end{array}$ & $\begin{array}{l}\text { Water table } \\
\text { depth }(\mathrm{mm})\end{array}$ & $\begin{array}{l}\text { Coarse } \\
\text { sand }\end{array}$ & $\begin{array}{l}\text { Medium } \\
\text { sand }\end{array}$ & $\begin{array}{l}\text { Fine } \\
\text { sand }\end{array}$ & $\begin{array}{l}\text { Coarse } \\
\text { silt }\end{array}$ & $\begin{array}{c}\text { Fine } \\
\text { silt }\end{array}$ & Clay \\
\hline \multicolumn{9}{|l|}{ Vaalharts site } \\
\hline Virgin sand (Hutton) & None & None & 12 & 14 & 61 & 5 & 2 & 7 \\
\hline Irrigated sand (Bainsvlei) & Flood & 1600 & 9 & 11 & 67 & 2 & 2 & 8 \\
\hline Irrigated. and drained sand (Bainsvlei) & Flood & 1000 & 10 & 11 & 69 & 2 & 2 & 6 \\
\hline Virgin clay (Valsrivier) & None & None & 5 & 5 & 33 & 5 & 7 & 46 \\
\hline Irrigated clay (Valsrivier) & Flood & None & 5 & 5 & 46 & 4 & 5 & 34 \\
\hline \multicolumn{9}{|l|}{ Spitskop site } \\
\hline Virgin clay (Arcadia) & None & None & 2 & 2 & 26 & 2 & 11 & 57 \\
\hline Irrigated clay (Arcadia) & Flood & None & 2 & 2 & 27 & 2 & 10 & 58 \\
\hline \multicolumn{9}{|l|}{ Wildeklawer site } \\
\hline Virgin sand (Hutton) & None & None & 1 & 27 & 60 & 2 & 1 & 7 \\
\hline Irrigated sand (Bainsvlei) & Centre pivot & None & 1 & 23 & 55 & 3 & 6 & 12 \\
\hline \multicolumn{9}{|l|}{ Zandbult site } \\
\hline Virgin sand (Hutton) & None & None & 5 & 22 & 65 & 1 & 2 & 5 \\
\hline Irrigated sand (Hutton) & Centre pivot & None & 6 & 24 & 60 & 1 & 3 & 5 \\
\hline \multicolumn{9}{|l|}{ Jackson site } \\
\hline Virgin sand (Bloemdal) & None & 1300 & 4 & 8 & 65 & 4 & 4 & 13 \\
\hline Irrigated sand (Bloemdal) & Centre pivot & 1100 & 3 & 21 & 61 & 2 & 3 & 8 \\
\hline Irrigated clay (Sepane) & Flood & 1200 & 3 & 4 & 30 & 5 & 10 & 48 \\
\hline Irrigated and drained clay (Sepane) & Flood & None & 3 & 4 & 34 & 7 & 12 & 39 \\
\hline
\end{tabular}




\begin{tabular}{|l|c|c|c|c|}
\hline \multicolumn{5}{|c|}{$\begin{array}{c}\text { TABLE 3 } \\
\text { Long-term mean and minimum and maximum } \\
\text { values of some water quality variables in the } \\
\text { segments of the Lower Vaal River }\end{array}$} \\
\hline \multirow{2}{*}{ Sites } & \multicolumn{2}{|c|}{$\begin{array}{c}\text { Electrical } \\
\text { conductivity (ms-m }{ }^{-1} \text { ) }\end{array}$} & $\begin{array}{c}\text { Sodium adsorption } \\
\text { ratio }\end{array}$ \\
\cline { 2 - 5 } & Mean & Min - Max & Mean & Min - Max \\
\hline $\begin{array}{l}\text { Vaalharts and } \\
\text { Spitskop }\end{array}$ & 52.22 & $25-100$ & 1.17 & $0.4-2.0$ \\
\hline Wildeklawer & 53.9 & $25-80$ & 1.29 & $0.4-2.1$ \\
\hline Zandbult & 71.7 & $50-100$ & 1.78 & $1.0-2.2$ \\
\hline
\end{tabular}

belong to the Valsrivier (Vertic Paleargid), Sepane (Vertic Haplargids) and Arcadia forms (Haplotorrerts). The Hutton soils are deep sandy, freely drained, eutrophic, dominantly red soils originating from aeolian deposits. The clayey soils are deep, with a strong structure and swelling clays. The Bainsvlei, Bloemdal and Sepane soils have grey, yellow and red mottles in the subsoil. These are indications of intermittent subsoil saturation. Mottles were absent in irrigated soils without water tables and the virgin soils of the study area.

Irrigation water quality deteriorated downstream from Vaalharts to Jackson (Table 3), but nevertheless remained within the C2S1 class (Du Preez et al., 2000). Values of EC and sodium adsorption ratio (SAR) increased with approximately $40 \%$ and $60 \%$, respectively and the probability of soils becoming saline and sodic, or both, therefore increased downstream (Table 3). An additional factor promoting this tendency is the increasing aridity from Vaalharts to Jackson as revealed by the data in Table 1. The evaporative demand was $696 \mathrm{~mm}$ more, and the rainfall $127 \mathrm{~mm}$ less, at Jackson than at Vaalharts (Table 1). With regard to salinity hazard there is a wide variation in conditions between the sites. It is therefore expedient to initially discuss the results for each site separately, and thereafter to draw any general conclusions. Salinity profiles are presented for sandy and clayey soils, respectively, in Figs. 2 and 3.

a
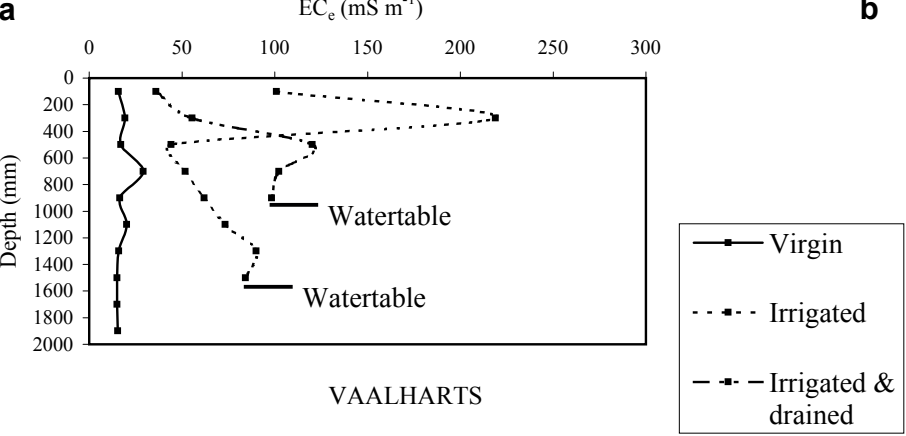

C

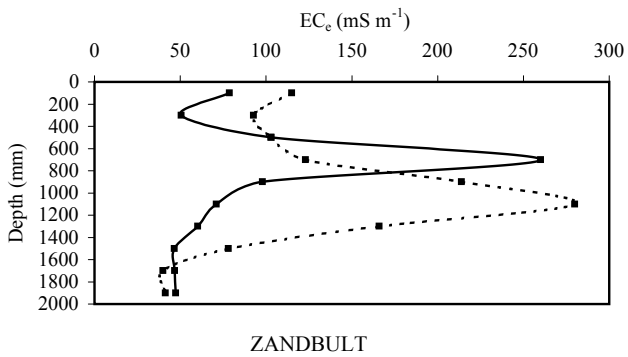

b

d

\section{Sandy soils}

Vaalharts: The irrigated sandy soils had mottles visible in the subsoil - at depths less than $1000 \mathrm{~mm}$ in the irrigated and drained soil, and less than $1600 \mathrm{~mm}$ in the irrigated soil (Fig. 2a). The mottles indicate intermittent water logging at the respective depths. The virgin Hutton soil is assumed to be in phase with the climate and other soil-forming factors. It is therefore reasonable to expect that, before irrigation was applied, the salinity profiles of both irrigated soils would have been similar to that of the Hutton. Salt accumulation has occurred in the irrigated soils at depths of between 300 and $600 \mathrm{~mm}$ but only reached significantly high concentrations in the irrigated site. The salinity at $300 \mathrm{~mm}$ depth can affect the growth of sensitive crops (Ayers and Westcot, 1976). Capillary rise from a water table with increased salt content is probably the main cause of salt accumulation in these soils. The beneficial influence of drainage on the irrigated and drained soil is well demonstrated in Fig. 2a.

Wildeklawer: The salt content of the virgin Hutton was about double that at Vaalharts. Leaching is probably lower due to a lower aridity index (data not shown). Although a water table was not found in the irrigated Bainsvlei soil, mottles occurring at 1 $200 \mathrm{~mm}$ depth indicated periodic water logging. Salt accumulation at 400 to $1000 \mathrm{~mm}$ depth rather indicated accumulation where plant roots extract water (Fig. 2b). These concentrations can affect sensitive crops (Ayers and Westcot, 1976). Irrigation scheduling only allowed for replacement of crop water use and limited leaching under centre-pivot irrigation may therefore be the main cause for salt accumulation at Wildeklawer.

Zandbult: The salt profile (Fig. 2c) was anomalous for this deep sandy Hutton soil. Although the virgin site was selected in natural veld, the farmer later indicated that it could have been affected by irrigation with water of poor quality some years ago. This could explain the considerable accumulation restricted to a layer 400 to $800 \mathrm{~mm}$ deep. A similar accumulation pattern also occurred in the irrigated soil at a slightly lower depth, evidently
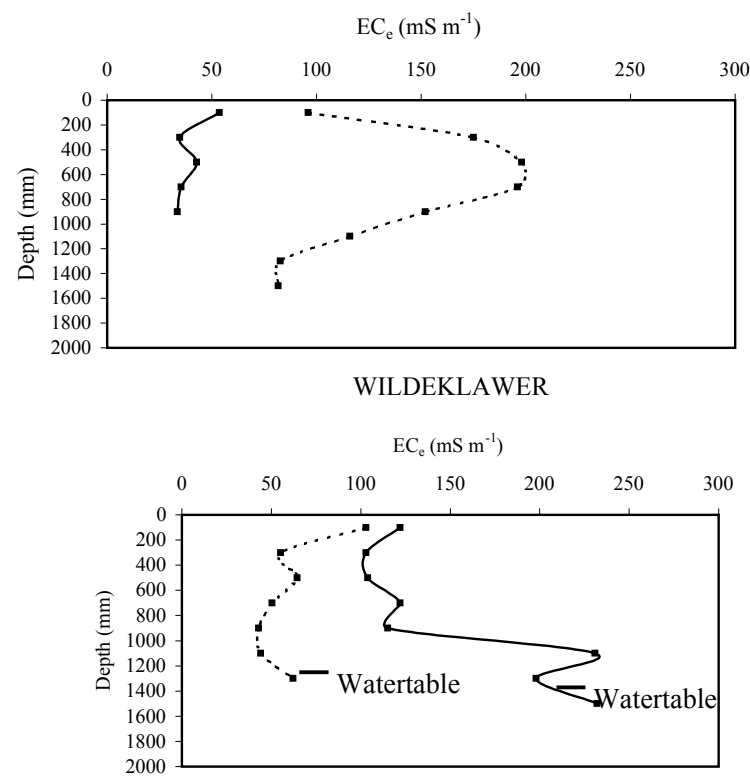

Figure 2

Profiles of electrical conductivity $\left(E C_{e}\right)$ in the sands 


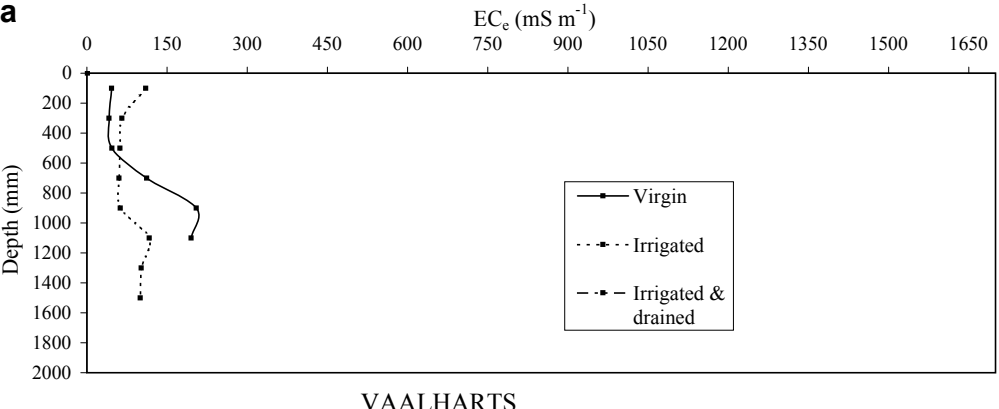

b

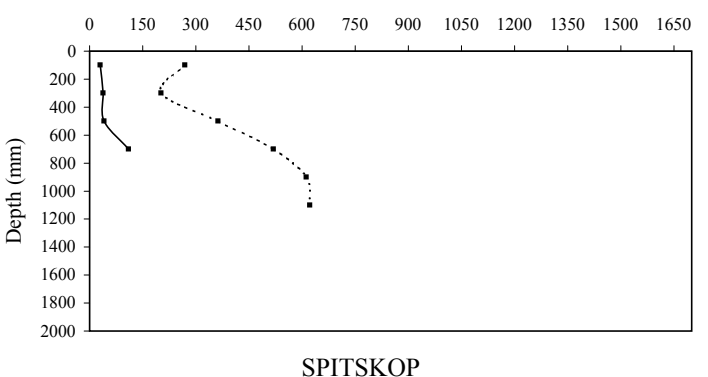

C

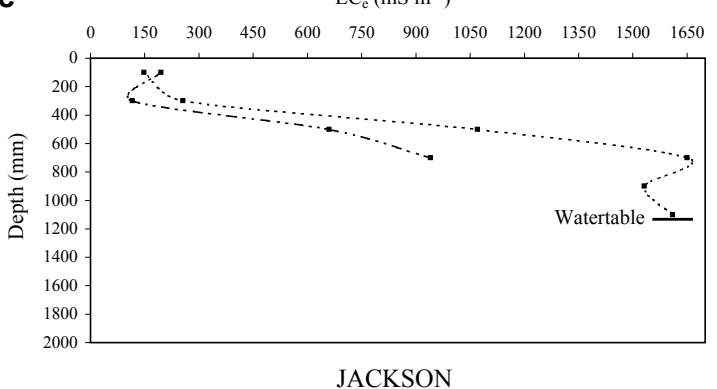

Figure 3

Profiles of electrical conductivity $\left(E C_{e}\right)$ in the clays

due to a certain amount of leaching. These concentrations can affect sensitive crops (Ayers and Westcot, 1976).

Jackson: The salt distribution profiles in the virgin Bloemdal soil (Fig. 2d) may be due to the dry climate of the area (Table 1). The water table probably originates from the irrigation plot. The salt accumulation above the water table of the irrigated soil is an indication that water uptake by plant roots and water supply by capillary rise may be the major forces in the profile's salt distribution. The salinity in the deep layers of the virgin soils can affect sensitive crops (Ayers and Westcot, 1976).

\section{Clayey soils}

Vaalharts: Minimal salt accumulation has occurred in the topsoil of the irrigated Valsrivier form soil and it seems that enhanced leaching caused by flood irrigation, and a satisfactory permeability, has reduced the salt content of the subsoil despite the high clay content of $34 \%$ (Fig. 3a). Relatively good permeability was expected from this red, calcareous soil of the Valsrivier form.

Spitskop: Leaching has clearly been inadequate in the subsoil of this extremely swelling clayey soil (Fig. 3b). Salt accumulated in the irrigated soil. The concentration in the topsoil $(0-200 \mathrm{~mm})$ exceeds $130 \mathrm{mS} \cdot \mathrm{m}^{-1}$ and will influence production of sensitive crops. Salinity increase with depth and below 400 $\mathrm{mm}$ the salt content exceeded the $300 \mathrm{mS} \cdot \mathrm{m}^{-1}$ threshold value for moderately sensitive crops, reaching $600 \mathrm{mS} \cdot \mathrm{m}^{-1}$ at $800 \mathrm{~mm}$ where it may affect moderately tolerant crops. Salinity levels above the threshold could induce plant water stress (Ayers and Westcot, 1976), even if the soil water content is at field capacity. The plants may wilt because the roots are unable to absorb the water, as a result of the osmotic effect of salts in the soil solution. Such high salinity may eventually also result in salt toxicity if plants accumulate excess salt.
Jackson: Extensive salt accumulation has evidently occurred in this Sepane clayey soil after about 60 years of irrigation. Salinity in the topsoil exceeds the threshold value for sensitive crops and reaches a seriously harmful value of $1650 \mathrm{mS} \cdot \mathrm{m}^{-1}$ that will affect growth of tolerant crops at a depth of about $700 \mathrm{~mm}$ (Fig. 3c). Drainage, installed about 15 years before the sampling was done, has been beneficial to some extent. The farmer reported increased yields the first year after the drains had been installed.

The following general conclusions can be drawn from the data presented. $\mathrm{EC}_{\mathrm{e}}$ was in most cases higher in the irrigated than the virgin soils. The general threshold $\mathrm{EC}_{\mathrm{e}}$ for crop production (400 $\mathrm{mS} \cdot \mathrm{m}^{-1}$ ) was exceeded only in the irrigated clays of Spitskop and Jackson from $400 \mathrm{~mm}$ and deeper. The $\mathrm{EC}_{\mathrm{e}}$ of the virgin sands increased downstream and was $c .20 \mathrm{mS} \cdot \mathrm{m}^{-1}$ at Vaalharts, $c .40$ $\mathrm{mS} \cdot \mathrm{m}^{-1}$ at Wildeklawer and $c .110 \mathrm{mS} \cdot \mathrm{m}^{-1}$ at Zandbult and Jackson (Fig. 2). This gradient is probably related to effective rainfall which decreases in the same direction (Table 1), causing a decrease in the efficiency of leaching under natural conditions.

It appears as if the $\mathrm{EC}_{\mathrm{e}}$ of the sandy soils tends to equilibrate between 50 and $200 \mathrm{mS} \cdot \mathrm{m}^{-1}$ under irrigation (Fig. 2). The distribution of salts in these profiles may reflect an equilibrium condition of removal of salts by leaching, accumulation of salts due to water uptake by plants, and supply of salts by capillary rise from the water table. The accumulation of salts, as indicated by the higher $\mathrm{EC}_{\mathrm{e}}$-values in the subsoil of the irrigated sands are related to the presence of water tables at Vaalharts and Jackson, and centre-pivot irrigation at Wildeklawer and Zandbult. The water tables deposited salts 200 to $400 \mathrm{~mm}$ higher up in the profile through capillary rise and plant-root water uptake. Centre pivot irrigation was carefully scheduled for optimum water use, which prevented leaching. Salts therefore accumulated in the $0 \mathrm{~mm}$ to $1200 \mathrm{~mm}$ zone.

The $\mathrm{EC}_{\mathrm{e}}$ of the clayey soils varied between $\mathrm{x} \mathrm{mS} \cdot \mathrm{m}^{-1}$ and $\mathrm{y}$ $\mathrm{mS} \cdot \mathrm{m}^{-1}$ under irrigation (Fig. 3). The profiles of $\mathrm{EC}_{\mathrm{e}}$ in the irrigated clays of Spitskop and Jackson were typical of limited salt 


\begin{tabular}{|l|c|c|c|}
\hline \multicolumn{4}{|c|}{ SABLE 4 } \\
\hline \multirow{4}{*}{ Site } & Profile & $\begin{array}{c}\text { Salt load } \\
\left(\mathbf{k g} \cdot \mathbf{h a}^{-1} \cdot \mathbf{m}^{-1} \mathbf{)}\right.\end{array}$ & $\begin{array}{c}\text { Difference from } \\
\text { reference } \mathbf{~ p r o f i l e ~} \\
\left(\mathbf{k g} \cdot \mathbf{h a}^{-1} \cdot \mathbf{m}^{-1} \mathbf{)}\right.\end{array}$ \\
\hline Vaalharts & Virgin sand & 423 & \\
\cline { 2 - 4 } & Irrigated sand & 2002 & +1579 \\
\cline { 2 - 4 } & Irrigated. and drained sand & 2022 & +1599 \\
\cline { 2 - 4 } & Virgin clay & 5420 & \\
\cline { 2 - 4 } & Irrigated clay & 4379 & -1041 \\
\hline Spitskop & Virgin clay & 2578 & \\
\cline { 2 - 4 } & Irrigated clay & 22864 & +20286 \\
\hline Wilde-klawer & Virgin sand & 1469 & +3076 \\
\cline { 2 - 4 } & Irrigated sand & 4545 & \\
\hline Zandbult & Virgin sand & 2338 & +1057 \\
\cline { 2 - 4 } & Irrigated sand & 3395 & -2749 \\
\hline Jackson & Virgin sand & 4617 & \\
\cline { 2 - 4 } & Irrigated sand & 1868 & -61906 \\
\cline { 2 - 4 } & Irrigated clay & 84750 & \\
\cline { 2 - 4 } & Irrigated and drained clay & 22844 & \\
\hline
\end{tabular}

leaching combined with irrigation with low quality water (Bohn, 1985). Although the water quality at Vaalharts and Spitskop was similar (Table 3), restricted salt leaching at Spitskop could be attributed to a higher clay content as well as a higher content of swelling clays in the soil compared to that in Vaalharts (Fig. 3). The salt load calculated as the mass salt per meter soil depth, serves as an indication of the total accumulation of salts irrespective of the distribution in the profile. The salt load of the virgin sands increased downstream from $423 \mathrm{~kg} \cdot \mathrm{ha}^{-1} \cdot \mathrm{m}^{-1}$ at Vaalharts to $4617 \mathrm{~kg} \cdot \mathrm{ha}^{-1} \cdot \mathrm{m}^{-1}$ at Jackson (Table 4). No conclusion in this regard can be made for the virgin clays due to a lack of data. The salt load of the irrigated soils was higher than that of the virgin soils, except for the clay of Vaalharts and the sand of Jackson where it was respectively $1041 \mathrm{~kg} \mathrm{ha}{ }^{-1} \cdot \mathrm{m}^{-1}$ and $2749 \mathrm{~kg} \cdot \mathrm{ha}^{-1} \cdot \mathrm{m}^{-1}$ lower. The increase of the salt load as a result of irrigation varied from $626 \mathrm{~kg} \cdot \mathrm{ha}^{-1} \cdot \mathrm{m}^{-1}$ in the sandy loam of Wildeklawer to 20286 $\mathrm{kg} \cdot \mathrm{ha}^{-1} \cdot \mathrm{m}^{-1}$ in the clay of Spitskop. Artificial drainage decreased the salt load of the clay at Jackson by $61906 \mathrm{~kg} \cdot \mathrm{ha}^{-1} \cdot \mathrm{m}^{-1}$.

\section{Summary and conclusions}

Degradation of irrigated land to the point where it affects crop production can be the result of one, or a combination of a number of factors, viz. poor water quality, limited leaching, soil texture and restricted drainage. The contribution of poor water quality alone to the degradation of irrigation land in the Lower Vaal River could not be confirmed. Restricted leaching or drainage controlled by soil texture and sub-optimal irrigation conditions resulted in salt accumulation.

Limited leaching poses a threat therein that salt accumulation in the lower part of the root zone and below the root zone can occur. The rainfall is too low to continuously play a significant role in leaching of accumulated salts. Leaching is limited when scheduled irrigation with mechanical systems like centre pivots merely recharge water depletion by crops. Farmers increasingly prefer this option as it saves on costs. Furthermore, a high content of swelling clays in the soil profile also may limit leaching, which could result in the accumulation of salts. Worse conditions for salt accumulation are expected with centre-pivot irrigation on clayey soils.
Flood irrigation enhances leaching, but results in the appearance of water tables in the subsoil of sandy and clayey soils of the area. Restricted drainage and resulting shallow water tables play a role in salt accumulation in sandy and clayey soils.

Sandy and clayey soils with restricted drainage were successfully reclaimed by artificial drainage. However, for some clayey soils the saturated hydraulic conductivity seems to be to low and it may therefore be impossible to drain soils such as the Spitskop clay.

Salt accumulated in most profiles, but the soils have not degraded severely physically - at least not yet. Based on the $\mathrm{EC}$ of the irrigation water and the $\mathrm{EC}_{\mathrm{e}}$ of the soil, the infiltration rates and saturated hydraulic conductivity of the soils are probably not affected at all. These processes, however, are also affected by the SAR (DWAF, 1996), which is not fully reported on for the soils evaluated in this article. Increased salt contents are only present in some subsoils.

A major part of the soils can accommodate a small leaching factor without water logging and therefore the salt balance of the soils can be controlled by improved management. Land with restricted natural drainage may require more inputs as artificial drainage. Water logging, salinisation and sodicity of water and soils should be monitored in the long run to evaluate the seasonal and long-term variation. Due to temporal and spatial variation in the factors controlling salinity, effective irrigation scheduling which allows for leaching must be promoted.

\section{Acknowledgements}

The Water Research Commission is gratefully acknowledged for the financial support of this study. Our sincere appreciation to all the farmers for their kind co-operation as well as Dr. Malcolm Hensley for the thorough editing of this paper.

\section{References}

AYERS RS and WESTCOT DW (1976) Water Quality for Agriculture. Irrigation and Drainage Paper 29. FAO, Rome.

BACKEBERG GR (2003) Water usage and irrigation policy. In: L Nieuwoudt and J Groenewald (eds.) The Challenge of Change: Agri- 
culture, Land and the South African Economy. University of Natal Press, Pietermaritzburg, South Africa.

BOHN HL, McNEAL BL and O'CONNOR GA (1985) Soil Chemistry. John Wiley and Sons, New York.

DEPARTMENT OF WATER AFFAIRS AND FORESTRY (1996) South African Water Quality Guidelines ( $2^{\text {nd }}$ edn.). Volume 4: Agricultural Use: Irrigation. Department of Water Affairs and Forestry, Pretoria, South Africa.

DU PREEZ CC, STRYDOM MG, LE ROUX PAL, PRETORIUS JP, VAN RENSBURG LD and BENNIE ATP (2000) Effect of Water Quality on Irrigation Farming along the Lower Vaal River: The Influence on Soils and Crops. WRC Report No. 740/1/00. Water Research Commission, Pretoria, South Africa.

LAND TYPE SURVEY STAFF (1986) Land types of the maps SE27/20 Witdraai, 2720 Noenieput, 2722 Kuruman, 2724 Christiana, 2820 Upington, 2822 Postmasburg. Mem. Agric. Natl. Resour. S. Afr. No 3. Dept of Agriculture and Water Supply, Pretoria, South Africa.

MAAS EV (1986) Salt tolerance of plants. Appl. Agric. Res. 1 12-26.

NELL JP and VAN DEN BERG HM (2001) The Use of the South African Land-Cover Project for National State of Irrigation Reporting Congress of the South African Irrigation Institute, Durban, South Africa.

RICHARDS LA (1969) Diagnosis and Improvement of Saline and Alkali Soils. US Salinity Laboratory Handbook 60. USDA, Washington.
SWART, SJ, VAN VEELEN, M and NELL U (1991) Water Quality Data Inventory. Volume 1: Drainage Regions A, B, C, D, E, F. Technical Report TR 146. Department of Water Affairs and Forestry, Pretoria, South Africa.

SCOTNEY DM and VAN DER MERWE AJ (1995) Irrigation: Longterm Viability of Soil and Water Resources in South Africa. Proc. S. Afr. Irrig. Symp. WRC Report No. TT 71/95. Water Research Commission, Pretoria, South Africa.

SOIL CLASSIFICATION WORKING GROUP (1991) Soil Classification - A Taxonomic System for South Africa. Memoirs on the Agricultural Natural Resources of South Africa. No 15. Department of Agricultural Development, Pretoria, South Africa.

SOIL SURVEY STAFF (1999) Keys to Soil Taxonomy $\left(8^{\text {th }}\right.$ edn.). Pocahontas Press Inc., Blacksburg, Virginia.

THE NON AFFILIATED SOIL ANALYSIS WORK COMMITTEE (1990) Handbook of Standard Soil Testing Methods for Advisory Purposes. Soil Science Society of South Africa, P.O. Box 30030, Pretoria, South Africa.

WATER RESEARCH COMMISSION (1996) Policy Proposal for Irrigated Agriculture in South Africa. Discussion document prepared by Backeberg GR, Bembridge TJ, Bennie ATP, Groenewald JA, Hammes PS, Pullen RA and Thompson, H. WRC Report No. KV 96/96. Water Research Commission, Pretoria, South Africa.

WATER RESEARCH COMMISSION (1999) Agrimarket Survey: Commercial Farmers. Market Survey and Statistical Analysis Consultants. Pretoria, South Africa. WRC Internal Document. 